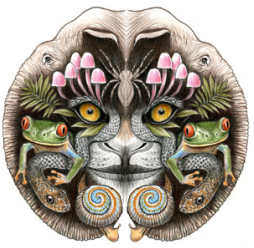

ISSN 0974-7907 (Online) ISSN 0974-7893 (Print)

OPEN ACCESS

\title{
NEW DISTRIBUTION RECORDS OF EPIOPHLEBIA LAIDLAWI TILLYARD, 1921 (INSECTA: ODONATA) IN BHUTAN
}

\author{
Tshering Dorji
}

College of Natural Resources, Royal University of Bhutan, Lobesa, Punakha, 14001, Bhutan tdorji1.cnr@rub.edu.bt

Abstract: An opportunistic survey for Epiophlebia laidlawi larvae was carried out within five districts in Western and Central Bhutan from 2012 to 2014 . The study recorded a total of 21 individuals from five districts and also recorded F0, F3 and F8 instars larvae for the first time in Bhutan. The study adds December and February as possible months to record $\mathrm{FO}$ instars within its range. The record of E. laidlawi from Bumthang District extends its range to the eastern most part of the Himalayas, and it also extends its range from Chhukha District to its southern most range within Bhutan. A record from Punakha District fills the gap between the previous and current record of $E$. laidlawi from Wangchhu basin in Western Bhutan and Drangmechhu basin spanning central and eastern Bhutan with Punatshangchhu basin in between. The record from Trongsa District emphasises the importance of the study area as E. laidlawi's habitat. The extent range of $E$. laidlawi within Bhutan is now extended to six districts, viz., Haa, Thimphu, Chhukha, Punakha, Trongsa and Bumthang.

Keywords: Anisozygoptera, Bhutan, distribution, Epiophlebia laidlawi, larva.
Epiophlebia laidlawi Tillyard, 1921 is one of the four species belonging to the order Odonata, suborder Anisozygoptera, family Epiophlebiidae. It is recorded from Nepal, India and Bhutan (Carle 2012). Species belonging to the genus Epiophlebia are considered relict species since they display features of both damselflies (Zygoptera) and dragonflies (Anisoptera) (Büsse et al. 2012). They resemble dragonflies in their general body outline, while they resemble damselflies in having similarly shaped and petiolate fore and hindwings (Büsse et al. 2012). Out of the four extant species of Epiophlebia, E. sinensis (Li et al. 2012) and E. diana (Carle 2012) were recently described from Heilongjiang and Sichuan provinces respectively in China, while E. laidlawi and $E$. superstes were described from India and Japan respectively (Brockhaus \& Hartmann 2009; Carle 2012;
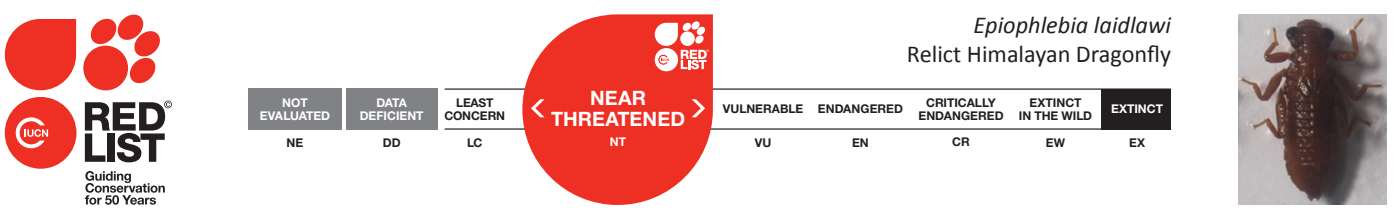

DOI: http://dx.doi.org/10.11609/JoTT.04092.7668-75 | ZooBank: urn:Isid:zoobank.org:pub:44355FD9-F7A9-435B-B911-46EAAB27D4E0

Editor: K.A. Subramanian, Zoological Survey of India, Kolkata, India.

Date of publication: 26 August 2015 (online \& print)

Manuscript details: Ms \# 04092 | Received 08 July 2014 | Final received 08 June 2015 | Finally accepted 28 July 2015

Citation: Dorji, T. (2015). New distribution records of Epiophlebia laidlawi Tillyard, 1921 (Insecta: Odonata) in Bhutan. Journal of Threatened Taxa 7(10): 7668-7675; http://dx.doi.org/10.11609/JoTT.04092.7668-75

Copyright: (c) Dorji 2015. Creative Commons Attribution 4.0 International License. JoTT allows unrestricted use of this article in any medium, reproduction and distribution by providing adequate credit to the authors and the source of publication.

Funding: Rufford Small Grants Foundation and Royal University of Bhutan.

Competing interests: The author declares no competing interests.
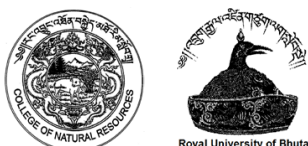

Acknowledgements: I would like to thank Ruffords Small Grants Foundation and Royal University of Bhutan for partially funding the current work. I would like to also thank the Ugyen Wangchuk Institute for Conservation and Environment (UWICE) for letting me participate in the freshwater biodiversity training workshop and workshop participants for dragonfly larvae. My special thanks are to Professor Anne Hartmann, Associate Porfessor Winsor Lowe and Associate Professor Amit Mitra for sharing their articles and / or resources, and students of the B.Sc. Sustainable Development $2^{\text {nd }}$ Batch, Diploma in Forestry, $22^{\text {nd }}$ Batch, Assistant Professor D.B. Gurung, College of Natural Resources for the field work in Trongsa, and other students who helped me in numerous field visits. I would also like to thank Mr. Ugyen Thinley, CNR for helping me generate GIS maps for the study area and results. Finally, I would like to thank the anonymous reviewer for their critical review and suggestions that enhanced the quality of the paper. 
Li et al. 2012). Out of the latter two species E. laidlawi is not well studied (Brockhaus \& Hartmann 2009; Büsse et al. 2012; Carle 2012; Li et al. 2012). It is assessed as Near Threatened based on its restricted range, insufficient data on its distribution and population size, and it being a relict species (Clausnitzer 2006).

E. laidlawi was recorded from Bhutan in 2006 (Brockhaus \& Hartmann 2009) from three districts, viz., Haa and Thimphu in western Bhutan, and Trongsa in central Bhutan from larval studies. The adult dragonfly studies in eastern Bhutan by Mitra $(2002,2006)$ and Mitra \& Thinley (2006), and in southeastern Bhutan by Mitra et al. (2012) failed to record adult E. laidlawi, and thus adult E. laidlawi is yet to be recorded from Bhutan (Brockhaus \& Hartmann 2009). Besides, larval development studies have been scanty for E. laidlawi, and it is very difficult to collect FO or the ultimate larva of the species, as it probably moves out of streams to live semi-terrestrially by April/May until it emerges like that of $E$. superstes. Previous studies have recorded FO of E. laidlawi only in March and October samples (Brockhaus \& Hartmann 2009). Therefore, with the difficulty of recording adults due to their short flight period (Brockhaus \& Hartmann 2009; Carle 2012) it is important to conduct exploratory larval distribution studies within its possible ranges. The current study aims at presenting the larval distribution of E. laidlawi in western and central Bhutan, and also to describe the larval development stage.

\section{Materials AND Methods \\ Study area}

The study area spans across five districts in Bhutan, viz.: Punakha, Thimphu and Chhukha in western Bhutan, Trongsa and Bumthang in central Bhutan. The streams sampled within Punakha are the headwater streams of Punatshangchhu basin, the streams within Thimphu and Chhukha districts form the part of Wangchhu basin, while the rivers and streams sampled within Trongsa and Bumthang form the part of Drangmechhu basin that spreads from central to eastern Bhutan (Wangchuk 2011) (Image 1). The details including district, a stream's name, reach notation, coordinates and altitude for all the sampled streams, rivers and reaches are given in Appendix 1. Different models of Garmin Handheld GPS were used to record coordinates and altitude in the different sampling areas (Images 2-4).

\section{Larval sampling}

The sampling for the larva was done as part of five different activities and D-frame nets $(25 \times 25 \mathrm{~cm})$ were used at all the reaches, except in Bumthang where kick nets $(30 \times 30 \mathrm{~cm})$ were used. The number of samples within each reach, and the number of reaches within each stream also varied from district to district. In Bumthang District sampling was done as a part of the training workshop conducted by the Ugyen Wangchuk Institute of Conservation and Environment on aquatic biodiversity, while in Trongsa District the Nikachhu

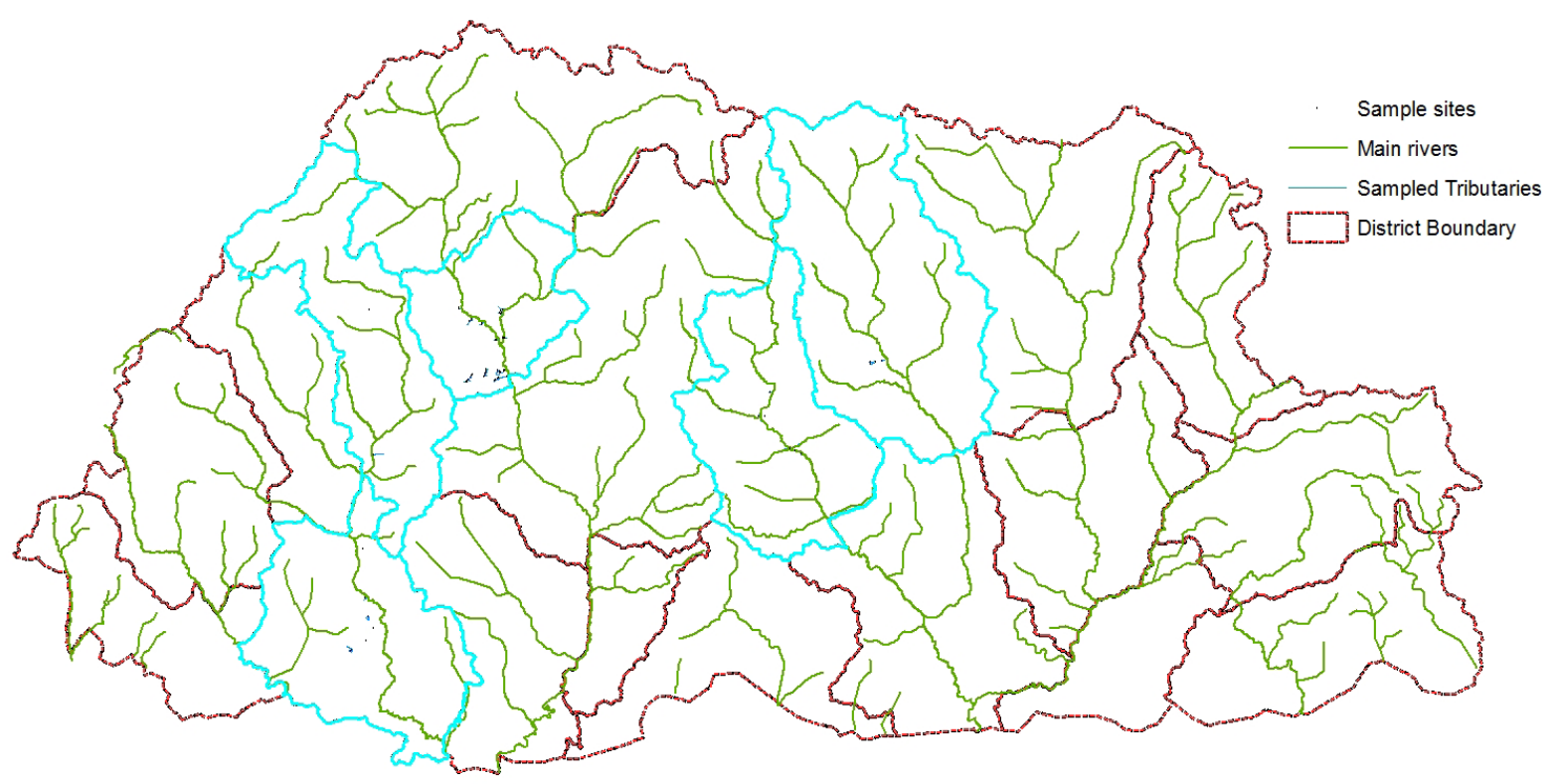

$1: 900,000$

Image 1. Drainage basin of Bhutan with sample sites and highlighted sampled districts. 

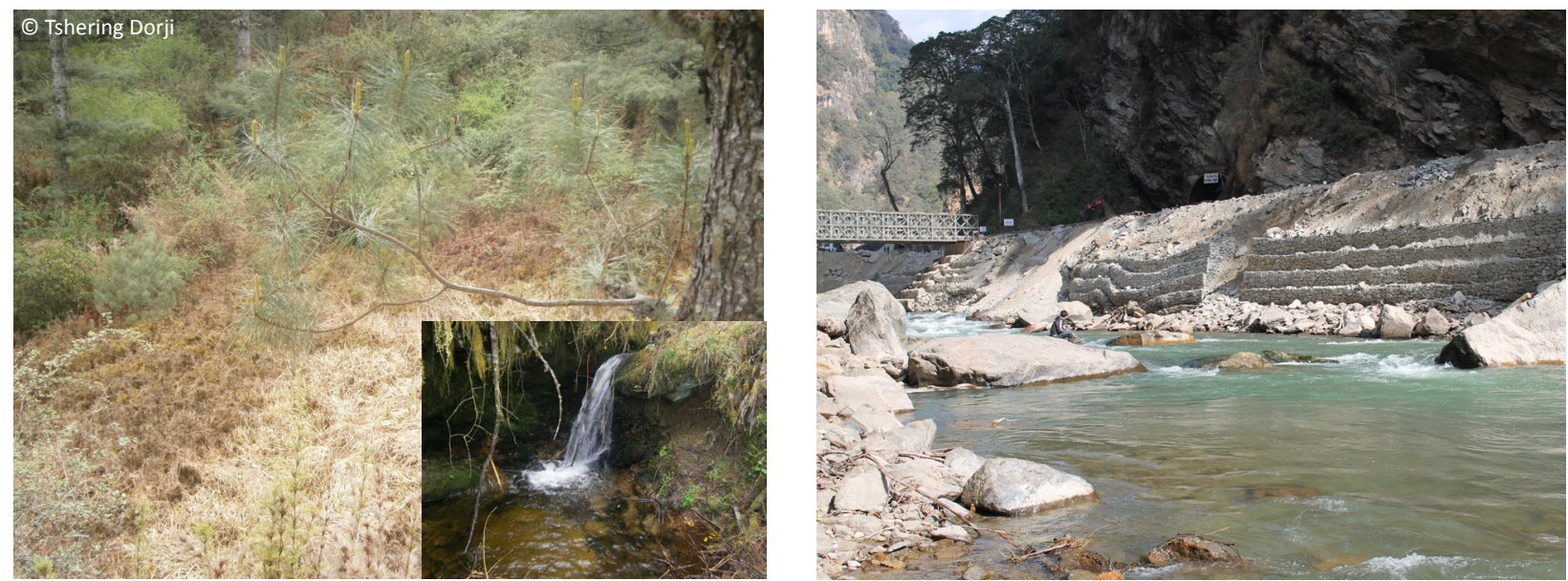

Image 2. Sampling reaches (a) Stream 1 (inset S1) in Bumthang, (b) Mangduechhu S4 in Trongsa.
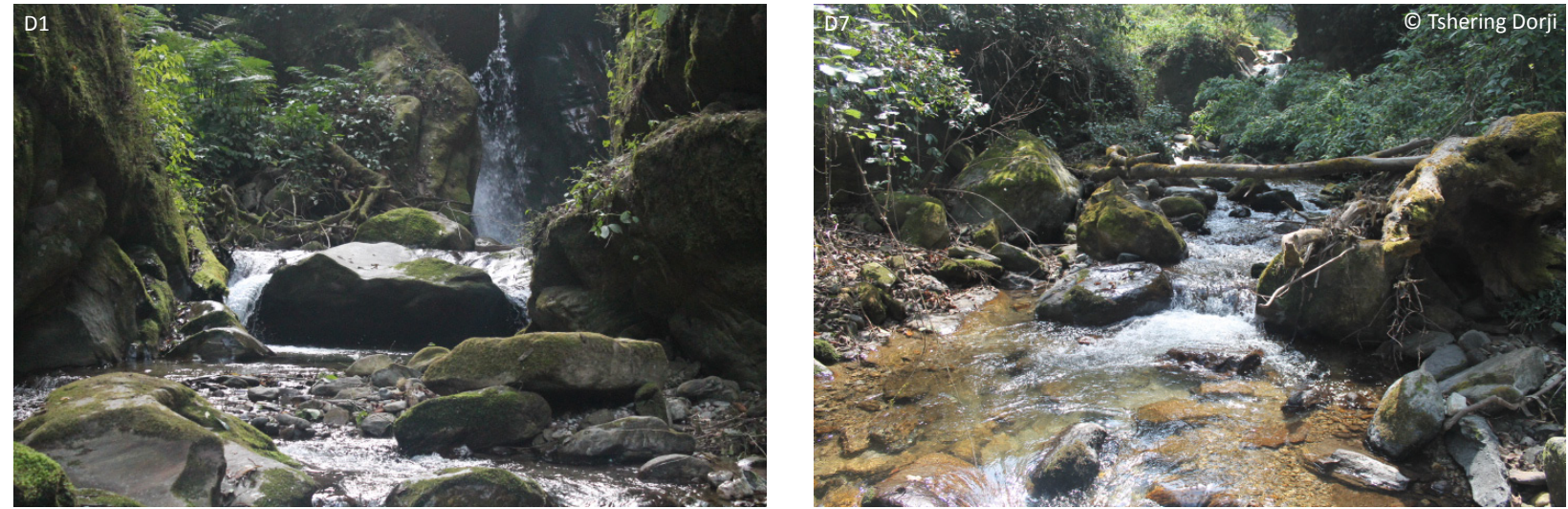

Image 3. Sampling reaches D1 and D7 in Dorokna Stream (pre monsoon season).

and Mangdechhu rivers were sampled as part of an aquatic biodiversity assessment from 1-5 December 2012. In Punakha the samplings were done as part of a macroinvertebrate research project and Odonata larval sampling work from October 2012 to March 2014, and other nine streams along Phochhu and Mochhu rivers were sampled as part of a field work by the students of the College of Natural Resources under the guidance of the author. In Thimphu and Chhukha districts nine streams along the Thimphu-Phuntsholing highway were sampled by the author between 2-6 February 2014 as an opportunistic survey. The larvae collected from the sampling sites were stored in glass jars or polyethylene bottles containing $70 \%$ ethanol. The larvae are currently deposited in the laboratory of the College of Natural Resources and voucher samples will be deposited in National Biodiversity Centre once proper storage facilities are developed within the centre. The larvae were indentified following Nesemann et al. (2011).

\section{Larval development stage}

A detailed measurement of body length from head to abdominal appendages and head capsule width from eye to eye were done using a digital vernier calliper. The reach of wing pad and sex of the larvae were determined for the collections from Bumthang, Thimphu and Chhukha following the work of Tabaru (1984), Brokhaus \& Hartmann (2009) and Nesemann et al. (2011). The larvae from Trongsa and Punakha districts were not studied in detail as they were discarded after taking photographs as the field works within the districts were done only to record their occurence.

\section{RESULTS}

During the study period a total of 21 E. laidlawi larvae were recorded (Table 1). Out of six larvae from Bumthang three were female and one male, while the sex of the other two could not be determined as they were young larvae with inconspicous ovipositor (Table 

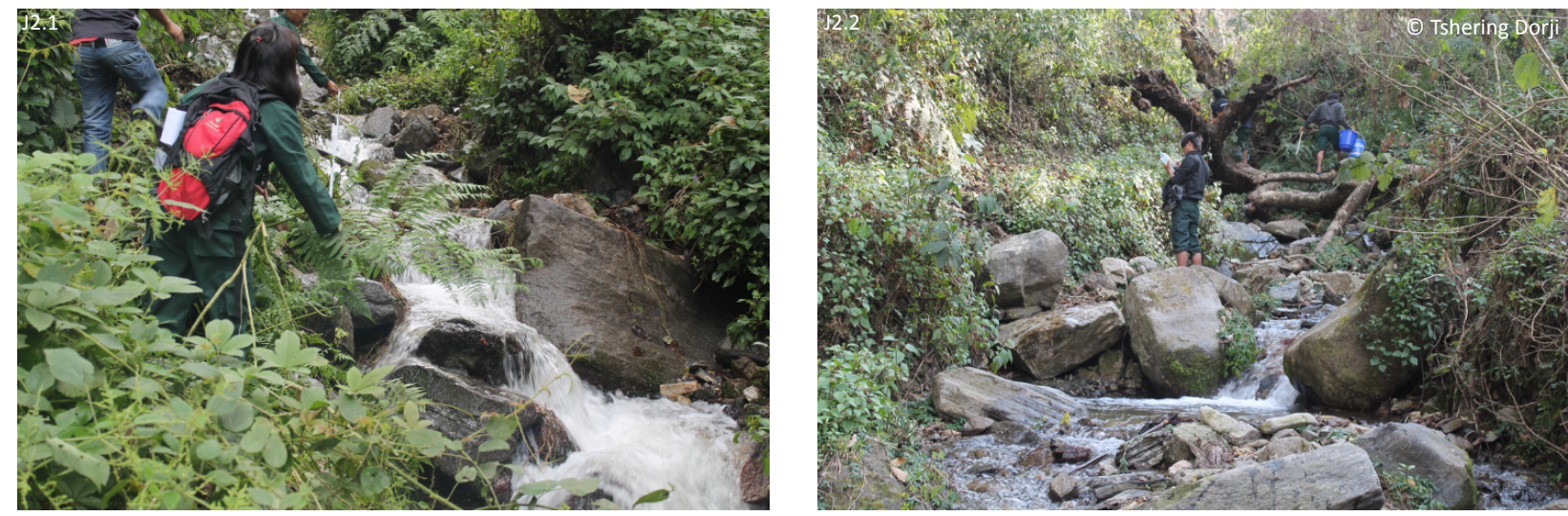

Image 4. Sampling reaches in Jichulum Stream: J2.1 (post monsoon) and J2.2( pre monsoon).

2; Images 5 \& 6). Even though larvae from other study areas were not studied in detail one larva from Nikachhu reach N2 is in F0 stage if judged from the image (Image 7).

\section{DISCUSSION AND CONCLUSION}

Records of E. laidlawi larvae from two streams in Bumthang District extends the distribution of E. laidlawi within Bhutan and in its current known range within the Himalaya to the eastern most part after Trongsa District, the earlier eastern most range. The record from Chhukha District extends its range to the southern most part in Bhutan. The record from Nikachhu River confirms the previous record from its tributary by Brockhaus \& Hartmann (2009) and shows the importance of the area as E. Laidlawi's habitat range. The record from Thimphu extends its range within the district southward after that of Brockhaus \& Hartmann (2009). Records of E. laidlawi larvae from Toebirongchhu sub-watershed in Dorokna
Table 1. Streams and reaches with district names and number of $E$. laidlawi larvae recorded.

\begin{tabular}{|c|c|c|}
\hline Stream and reach & District & No. of larvae \\
\hline Stream 1(S1) & Bumthang & 3 \\
\hline Stream 2(S2) & Bumthang & 3 \\
\hline Nikachhu (N1) & Trongsa & 2 \\
\hline N2 & Trongsa & 1 \\
\hline Dorokna (D1) & Punakha & 1 \\
\hline D2 & Punakha & 1 \\
\hline D7 & Punakha & 1 \\
\hline D8 & Punakha & 1 \\
\hline Jichulum (J1) & Punakha & 3 \\
\hline J2 & Punakha & 1 \\
\hline J3 & Punakha & 1 \\
\hline J4 & Punakha & 1 \\
\hline Drechhu(Dr1) & Thimphu & 1 \\
\hline Lobnekha(Lo1) & Chhukha & 1 \\
\hline
\end{tabular}

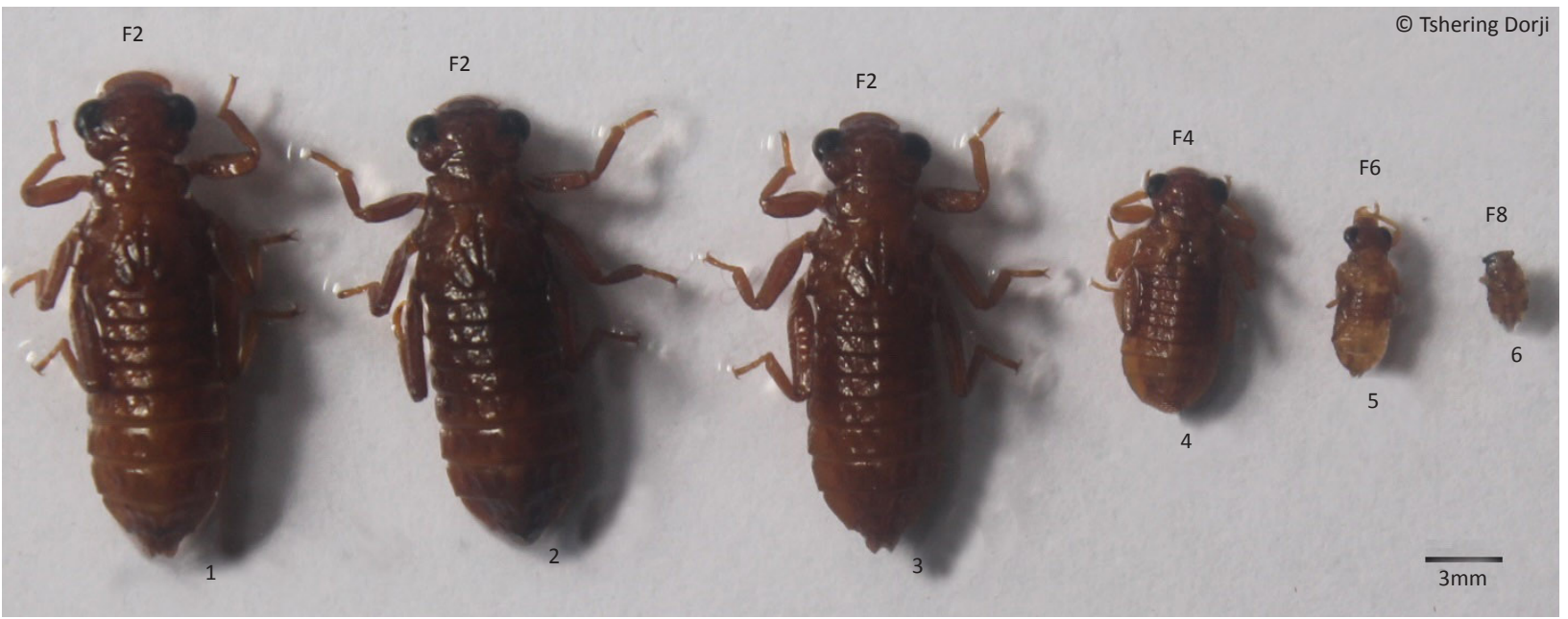

Image 5. Epiophlebia laidlawi larvae from two streams in Bumthang District with larva number (1-6) and larval stages. 
Table 2. Larval development stage with descriptions and sex of larva number 1-8.

\begin{tabular}{|c|c|c|c|c|c|c|c|}
\hline $\begin{array}{l}\text { Larvae } \\
\text { No. }\end{array}$ & Stream & Reach & $\begin{array}{l}\text { Body length } \\
\text { (mm) }\end{array}$ & $\begin{array}{l}\text { Head capsule } \\
\text { width }(\mathrm{mm})\end{array}$ & Wing pad & $\begin{array}{l}\text { Stage / } \\
\text { Instar }\end{array}$ & Sex \\
\hline 1 & Stream 1 & S1 & 15.2 & 4.2 & Touching $1^{\text {st }}$ abdominal segment & F2 & $\mathrm{F}$ \\
\hline 2 & Stream 2 & S2 & 15.1 & 4.2 & Touching $1^{\text {st }}$ abdominal segment & F2 & $\mathrm{F}$ \\
\hline 3 & Sream 1 & S1 & 15.1 & 4.2 & Touching $1^{\text {st }}$ abdominal segment & F2 & $\mathrm{F}$ \\
\hline 4 & Stream 1 & S1 & 8.8 & 2.9 & Reaching enterior margin of abdomen & F4 & M \\
\hline 5 & Stream 2 & S2 & 5.2 & 1.8 & Not developed & F6 & ND \\
\hline 6 & Stream 2 & S2 & 3 & 0.6 & Not developed & F8 & ND \\
\hline 7 & Lobnekha & Lo1 & 25.4 & 6.2 & $\begin{array}{l}\text { Reaches posterior margins of } 4^{\text {th }} \\
\text { abdominal segment }\end{array}$ & F0 & $\mathrm{F}$ \\
\hline 8 & Drechhu & Dr1 & 11 & 3.5 & Touching first abdominal segment & F3 & $\mathrm{F}$ \\
\hline
\end{tabular}

ND - Not able to determine.

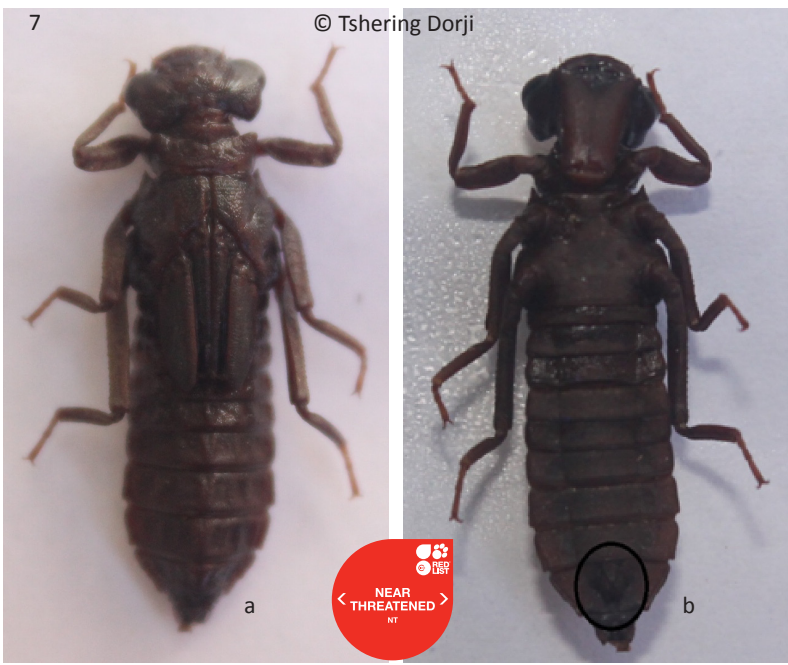

Image 6. Epiophlebia laidlawi larva in Lobnekha stream (a) dorsal view and (b) ventral view (ovipositor encircled).

and Jichulum streams add Punakha as the sixth district after Haa, Thimphu, Trongsa (Brockhaus \& Hartmann, 2009), Chhukha and Bumthang (Image 8). It also adds Punatshangchhu basin as another river basin with $E$. laidlawi and fills the gap between Wangchhu basin and Drangmechhu basin.

The failure to record E. laidlawi larvae from streams located southward than the Lobnekha Stream in Chhukha could be either due to limited sampling effort as only one kick sample per stream was done or it could have been due to its restricted range within colder streams (Brockhaus \& Hartmann 2009; Nesemann et al. 2011; Büsse et al. 2012; Carle 2012; Li et al. 2012). Streams and reaches within Toebirongchhu sub-watershed, along Phochhu and Mochhu, and Lamai Gonpa stream could be due to a relatively more disturbed habitat. Almost all streams and reaches from where the larvae were
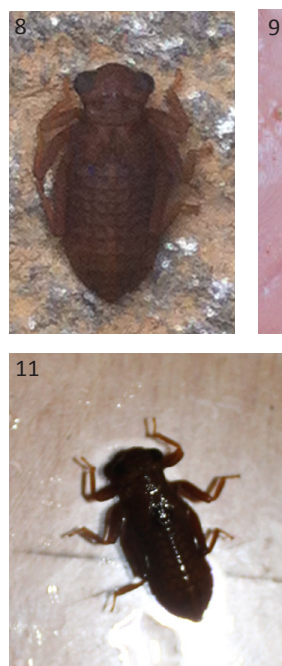

C) Tshering Dorji

Image 7. Epiophlebia laidlawi larvae from (8) Drechhu (Wangsisina), (9) Dorokna (D2), (10) Jichulum (J2), (11) Nikachu (N1), (12) Nikachhu (N1), and (13) Nikachhu (N2).

not recorded had high anthropogenic disturbance like abstraction of water for irrigation, dumping of waste material and reduced riparian vegetation. E. laidlawi is sensitive to human disturbance (Brockhaus \& Hartmann 2009; Nesemann et al. 2011). This possibly explains the absence of the species from the above mentioned localities.

The larval development stage adds to the record of FO from the whole E. laidlawi range and to the month of collection, thus adding to its poorly known biology (Brockhaus \& Hartmann 2009; Nesemann et al. 2011). The FO larvae were recorded from the March and October samples in previous studies (Brockhaus \& Hartmann 2009), while the current study collected it in February 2014 from Lobnekha Stream, while the the one from Nikachhu reach N2 was collected in December 2012. 


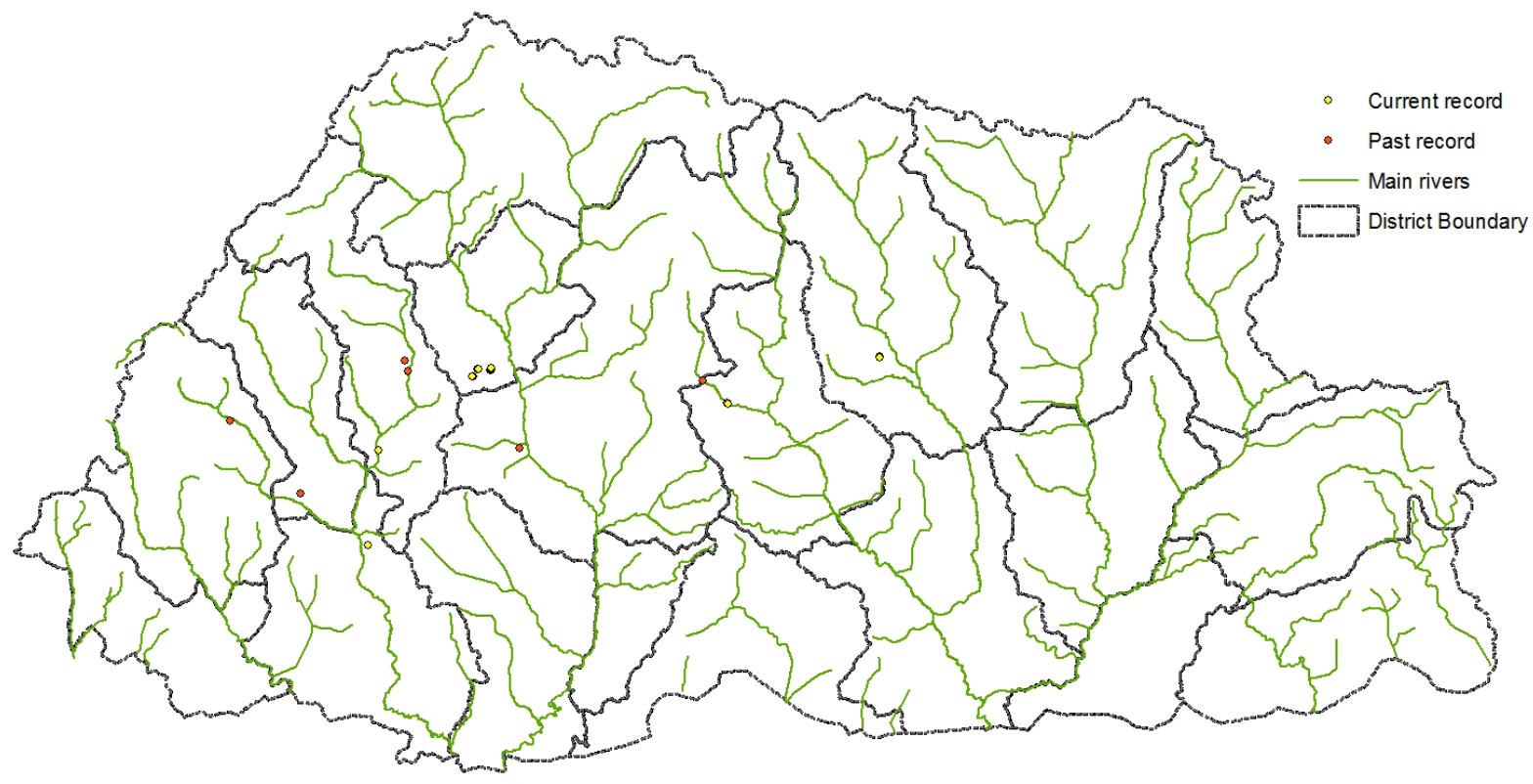

$1: 900,000$

Image 8. Past and current record of Epiophlebia laidlawi larval presence in Bhutan.

This confirms the presence of FO larva from October through, December and Februray till March. Besides, F3 and F8 are new instars described from Bhutan and adds to the list of larval stages described by Brockhaus \& Hartmann (2009).

The current study recorded larvae from new localities within Bhutan with very limited sampling effort and seasons. This may highlight chances of its widespread distribution within Bhutan thereby making Bhutan a safe haven for its conservation. However, it is currently not being recognised as a species of conservation concern in Bhutan. Therefore, there is need for a systematic survey of E. laidlawi's distribution within Bhutan and also to sensitize concerned stakeholders on its conservation status.

\section{REFERENCES}

Brockhaus, T. \& A. Hartmann (2009). New records of Epiophlebia laidlawi Tillyard, 1921 in Bhutan with notes on its biology, ecology, distribution, zoogeography and threat status (Anisozygoptera: Epiophlebiidae). Odonatologica 38(3): 203-215.

Büsse, S., P. von Grumbkow, S. Hummel, D.N. Shah, R.D.T. Shah, J. Li, X. Zhang, K. Yoshizawa, S. Wedmann \& T. Hörnschemeyer (2012). Phylogeographic analysis elucidates the influence of the ice ages on the disjunct distribution of relict dragonflies in Asia. Plos One 7(5): e38132; http://dx.doi.org/10.1371/journal.pone.0038132
Carle, F.L. (2012). A new Epiophlebia (Odonata: Epiophlebioidae) from China with a review of epiophlebian taxonomy, life history, and biogeography. Arthropod Systematics \& Phylogeny 70(2): 75-83.

Clausnitzer, V. (2006). Epiophlebia laidlawi. The IUCN Red List of Threatened Species. Version 2014.1. <www.iucnredlist.org>. Downloaded on 28 June 2014.

Li, J.K., A. Nel, X.P. Zhang, G. Fleck, M.X. Gao, L. Lin \& J. Zhou (2012). A third species of the relict family Epiophlebiidae discovered in China (Odonata: Epiproctophora). Systematic Entomology 37(2): 408-412; http://dx.doi.org/ 10.1111/j.1365-3113.2011.00610.x

Mitra, A. (2002). Dragonfly (Odonata: Insecta) Fauna of Trashigang Dzongkhag, eastern Bhutan. Environment and Life Support Systems of the Bhutan Himalaya 1: 40-70.

Mitra, A. (2006). Current status of the Odonata of Bhutan: A checklist with four new records. Bhutan Journal of Renewable Natural Resources 2(1): 136-143.

Mitra, A., K. Choden, Y. Dorji, T. Penjor, R. Dorji, K. Subedi \& P. Dorji (2012). Odonata of Samdrup Choling Dungkhag in Samdrup Jongkhar, Bhutan. Bhutan Journal of Research \& Development 1(2): 125-141.

Mitra, A. \& P. Thinley (2006). A report on the Odonata diversity of Bumdeling Wildlife Sanctuary, Trashi Yangtse, Eastern Bhutan. Ministry of Agriculture, Thimphu, 58pp.

Nesemann, H., R.D.T. Shah \& D.N. Shah (2011). Key to larval stages of common Odonata of Hindu Kush Himalaya, with short notes on habitats and ecology. Journal of Threatened Taxa 3(9): 2045-2060; http://dx.doi.org/10.11609/JoTT.o2759.2045-60

Tabaru, N. (1984). Larval development of Epiophlebia superstes in Kyushu. Tombo 26(1-4): 19-23.

Wangchuk, T. (2011). A report on Rapid Classification of Watersheds in the Punatsang Chhu Basin. Watershed Management Division, Department of Forests and Park Services, Ministry of Agriculture and Forest, Thimphu, 33pp. 
Appendix 1. Sampling reaches with district, stream name, sampling date, coordinates and altitude.

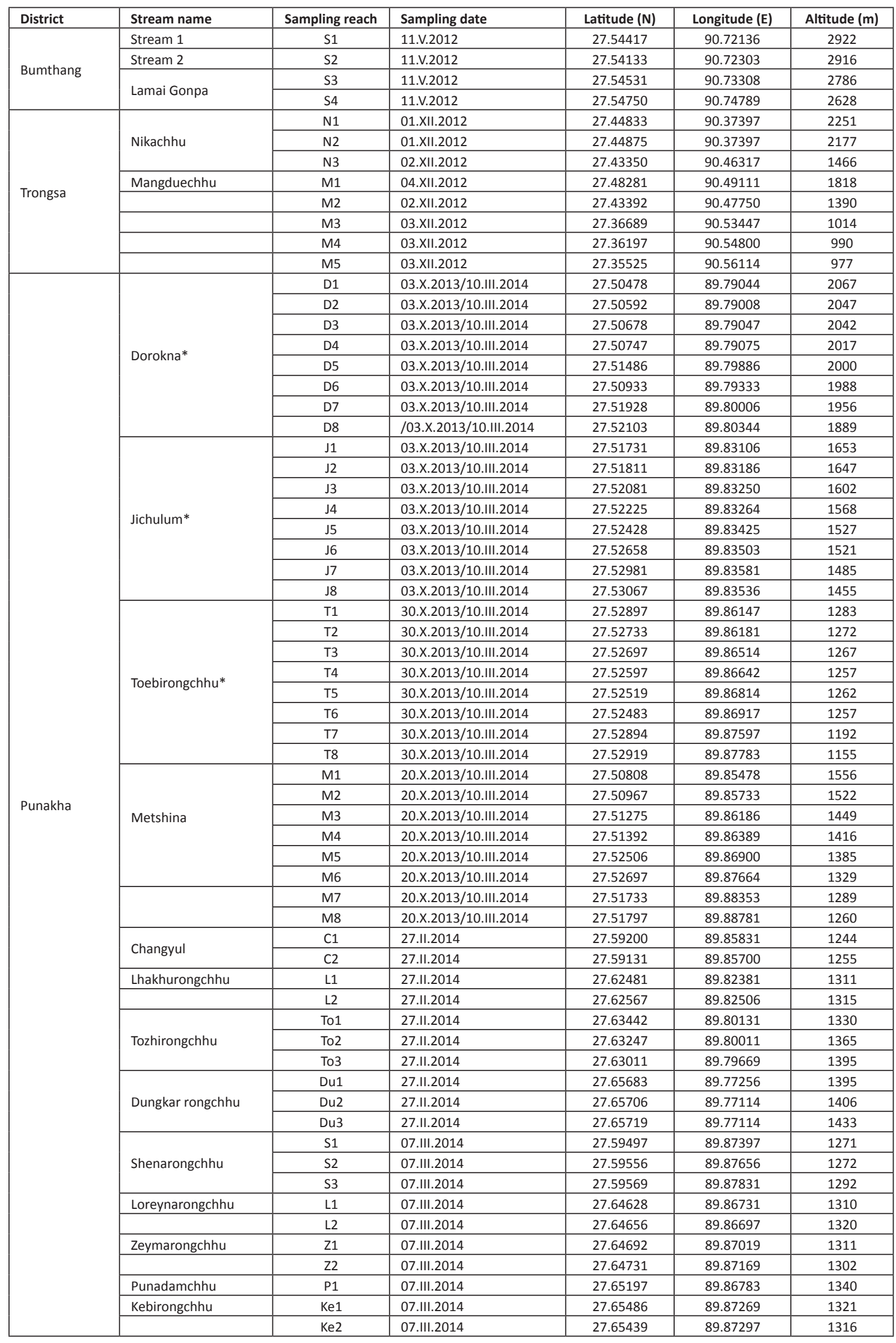




\begin{tabular}{|l|l|l|l|l|l|l|}
\hline \multirow{3}{*}{ Thimphu } & Drechhu (Wangsisina) & Dr1 & 02.11 .2014 & 27.35450 & 89.57431 & 2201 \\
\cline { 2 - 7 } & $\begin{array}{l}\text { Dagalarongchhu } \\
\text { (Geneykha) }\end{array}$ & Da1 & 02.11 .2014 & 27.65328 & 89.56508 & 2318 \\
\hline \multirow{5}{*}{ Chhukha } & Lobnekha & Lo1 & 02.11 .2014 & 27.16039 & 89.55092 & 2179 \\
\cline { 2 - 7 } & Stream 1 & CS1 & 02.11 .2014 & 27.05928 & 89.55633 & 1670 \\
\cline { 2 - 7 } & Takti & Ta1 & 02.11 .2014 & 27.02050 & 89.56375 & 1924 \\
\cline { 2 - 7 } & Tshatshilakha & Ts1 & $02 . I 1.2014$ & 26.99864 & 89.57567 & 2043 \\
\cline { 2 - 7 } & Stream 2 & CS2 & 06.11 .2014 & 26.97133 & 89.55922 & 2025 \\
\cline { 2 - 7 } & Gedu & Ge1 & 02.11 .2014 & 26.95175 & 89.52717 & 1915 \\
\cline { 2 - 7 } & Stream 3 & CS3 & 02.11 .2014 & & 89.52481 & 1845 \\
\hline
\end{tabular}

